\title{
Anxiety and Beliefs about English Language Learning: A Research on Gender
}

\author{
Illahi Bux Gopang ${ }^{1}$, Rafique A Memon ${ }^{2}$, Abdul Sattar Gopang ${ }^{3}$
}

\begin{abstract}
This study aimed to investigate gender differences among engineering students in anxiety and beliefs about English Language Learning at Mehran UET, Pakistan. The triangulation research design was employed to address research question and objective. The respondents $(\mathrm{N}=221)$ including 105 female and 116 male voluntarily participated and provided their responses on FLCAS and BALLI items. The semi-structured interviews were conducted to provide in-depth understanding of anxiety and beliefs as multi-faceted dimensions of emotions about language learning in a classroom. t-test was computed to check gender differences in anxiety and language beliefs of engineering students. The interview responses of the participants confirmed and corroborated the descriptive results. Quantitatively, the findings of the study indicated no gender differences in students' foreign language anxiety and language beliefs. Qualitatively, a semi structured interview data also supported the descriptive results. Through these results, this research discovers that anxiety and beliefs are significantly associated with leaners' foreign language learning. The current study on gender differences in terms of anxiety and beliefs confirmed previous studies and contributed convincingly in the exiting literature on anxiety and beliefs.
\end{abstract}

Keywords: Foreign Language Anxiety, Language Beliefs, Gender Differences

\section{Introduction}

The current research aimed to investigate and determine gender differences in foreign language learning and beliefs about language learning at tertiary level in Pakistan. Anxiety on gender affects and differences has generated a great deal of interest among researchers. Foreign language acquisition maintains the focus on learner's anxiety and the emphasis is also to address the issues related with language learning in classroom. It is suggested in the body of knowledge that anxiety interferes learning and it has its effects. But, it still needs

\footnotetext{
${ }^{1}$ Assistant Professor, IELL, University of Sindh Email: illahibux.gopang@usindh.edu.pk

${ }^{2}$ Professor, IELL, University of Sindh, Email: rafique.memon@usindh.edu.pk

${ }^{3}$ Assistant Professor, CD\&SE, Faculty of Education, University of Sindh

Email: a.s.gopang@gmail.com
} 
a detailed consideration that whether anxiety minimizes/maximizes among learners who are in different phases of learning, for example, in the beginning of university education course and completion of that course. Chao (2003) has suggested that research on anxiety support teachers and researchers to achieve better understanding of learning from student's perspectives. This type of research create appropriate ways for educators who design interventions and strategies to build self-confidence among learners and decrease the level of their anxiety. Second Language Anxiety (SLA) research confirms that foreign language anxiety is distinctively distinct phenomenon and has particular effects on second language learning. Anxiety is a very psychological issue related with language learning. It is however not taken so seriously in a classroom because teachers tend to neglect it and they only rush to complete courses (Gopang, 2016). This issue has negative effects on learners. There is a very limited research that focuses Foreign Language Anxiety (FLA) in this context. Only quantitative approach can not suffice studies because it does not listen to voices of learners. On the other hand, qualitative approach has tendency to record subjectively learners' emotional experiences (Dewaele \& Thirtle, 2009; Gregersen \& Horwitz, 2002). This idea was followed up and the current research was triangulated in Pakistani context.

\subsection{Objective of Study}

The objective of the current study included:

1. To find out gender differences in anxiety and beliefs of engineering students at tertiary level in Pakistan.

\subsection{Research Question}

The research question enquired of gender differences in anxiety and beliefs such as; what are the gender differences in learner anxiety and beliefs about language learning?

\section{Literature Review}

Language anxiety is basically a very important emotional construct that essentially influences foreign language learning and teaching (Smith, 2000). Lewis and Carpendale (2004) as cited in Zheng (2008) suggested that if researchers could intend to gain sound understanding of anxiety, they would better adopt a social cognitive approach in order to lay emphasis on integration of social and cognitive constructs. Dewaele and Thirtle (2009) conducted a research on young learners in order to identify inside variables that caused them to drop foreign languages. The study of Williams and Andrade (2008) suggested that learners have associated anxiety with teacher and other persons and its effects were caused by gender and perceived ability. The findings vary, but there 
is still recognizable pattern that might predict a connection between student anxiety and variable. On the other hand, many researchers tried to make up a complete picture of student's anxiety and its relationship with variables not only looking at one to one connection (Onwuegbuzie, Bailey \& Daley, 1999). They confirmed more than ten variables like age, academic achievement, prior history of visiting countries, gender and perceived self-worth, many of which relates to their opinions of different aspects of themselves. In the research, $(n=210)$, students at Mid Southern University, U.S.A, were surveyed in learning German, Japanese, French and Spanish respectively. The results indicated no statistical difference in the degree of anxiety among learners of different languages. In consideration, in research of Duxbury and Tsai (2010), no significant relationship was found among student's attitudes and anxiety towards cooperative learning.

The BALLI (beliefs about language learning inventory) has exclusively been employed in a bulk of studies on language beliefs. In the past decades, an investigation was carried out to relate beliefs and proficiency (Mantle-Bromley, 1995), the impact of culture on beliefs (Cortazzi \& Jin, 1996; McCarger, 1993; Horwitz, 1999), that of gender (Tercanlioglu, 2005), the dimensions underlying language learners' beliefs (Sakui, \& Gaines, 1999) and strategy use (Yang, 1999) in various countries. The extensive research conducted with the inventory shows that beliefs about language learning are context specific (Nikitina \& Furuoka, 2006). Beliefs are possibly linked with learner's earlier experience of language learning, life experience or cultural background. Significantly, what they trust about acquisition of language could affect how they treat their language and implement (Horwitz, 1987). The students' beliefs cannot lead them to successful learning of second/foreign language. Negative emotions may result from their dissatisfaction. Hence, it is necessary to get students' beliefs into consideration by debating their sources, and emotions which affect their learning (Horwitz, 1987). Furthermore, in Taxes University, she researched and stated that Spanish students also have language beliefs such as few languages are comparatively relaxed to learn, between two languages, learning a language is about translation; it is important to pronounce with native-like accent, adult need more efforts than child. Few beliefs are very unrealistic which lead to unpleasant experience of learning. Learners get depressed and frustrated when they realize that their achievement is nearly impossible for them. In language learning, learners may develop negative feelings about personal ability in the case of when those expectations are not met (Horwitz, 2010). Student's belief that language learning is based on limited experience, knowledge or the instructor's effective course can well confront erroneous beliefs and form new information. This method had been 
very useful with cluster of anxious language students in work. Language teachers who conduct their classes depend on their language teaching (Horwitz, 2013).

\subsection{Research Design}

\section{Research Methodology}

The present study employed a mixed methods approach to triangulate the results. Creswell (2013) has described that quantitative and qualitative methods are intermingled and linked to each other at the time when data are collected and analyzed. These two phases are connected in mixed methods research. Further, it was also added to the idea that researchers might concurrently gather data using mixed methods design and intermix or integrate both data bases by developing themes into counts and comparing these with quantitative or descriptive data. Creswell (2007) has written that in concurrent data collections, quantitative and qualitative are integrated and both are presented in research concurrently. This refers to two data bases merged simultaneously. In this study, the investigator follows this scenario of mixed methods approach in order to answer the specific research question and objective. A very clear perceptive of using mixed methods design is described above. This idea basically helped the researcher to follow up in his design by using a combined method.

\subsection{Population of Study}

Population of study included 221 participants including 116 male and 105 female students from various departments/disciplines/faculties. Population size is mentioned below;

\begin{tabular}{lc}
\hline Department & No. of participants \\
\hline Software Engineering & 30 \\
Civil Engineering & 30 \\
Bio-medical engineering & 40 \\
Computer Systems Engineering & 25 \\
Telecommunication Engineering & 20 \\
Electrical Engineering & 17 \\
Electronics Engineering & 20 \\
Petroleum and Gas & 20 \\
Mechanical & 19 \\
\hline Total & 221 \\
\hline
\end{tabular}




\subsection{Sample \& Sampling Technique}

The respondents (116 male and 105 female) were randomly selected for the study. The ratio of female participants was less. In MUET, the male students were greater in number than female counterparts. So the researcher could not balance the equal number of participants. The random sampling technique was employed as the most suitable one for the current study.

\subsection{Research Instruments}

Following research instrument were used:

\section{Foreign Language Classroom Anxiety Scale (FLCAS)}

Horwitz (1987) developed the scale known as FLCAS for anxiety investigation and measurement. The scale has been reported with high inter rater reliability (Aida, 1994). FLCAS consists of 33 items with possible range to 165; if the number is higher and as a result it indicates anxiety in high degree. The internal consistency in scale is reported .93, by using the sample of 108 participants in the study, while test-retest reliability was found .83 , and this period extended till 8 weeks (Horwitz, 1987). In the terms of construct validity, Foreign Language Classroom Anxiety is validated in the use of correlations by showing distinctiveness of the scale from other types of anxiety measurements (Horwitz, 2016). FLCAS is a self-report instrument; it is a standard instrument for anxiety measurement. This scale measures the level of foreign language anxiety acknowledged by negative performance, social comparisons, psychological symptoms and avoidance behaviors. The sources of developing FLCAS were 'student self-reports clinical experience, and a review of related instruments.

\section{Beliefs about Language Learning Inventory (BALLI)}

The BALLI was developed (Horwitz, 1988; revised version, 2013) to assess beliefs about language learning. This scale is employed to explore beliefs learner hold about language learning. It contains 34 statements scored on a Likert scale ranging from strongly agrees $=1$ ) to strongly disagree $5=$ ). Some items of BALLI were replaced according to the context of the present study. The statements 05 , 26, 'The language I am trying to learn is structured in the same way as English. The word English was replaced with mother tongue. 'I believe that I will ultimately learn to speak this language very well' (items 6 and 23). This language was changed to English. Americans are good at learning foreign languages' (statements, 30, 33). In the place of Americans, Pakistanis was used. Such changes were made to contextualize BALLI for present study. This instrument has been validated and considered a suitable tool for research on beliefs (Nikitina $\&$ Furuoka, 2006). Their study extracted four factors such as (1) motivation, (2) aptitude, (3) strategy, and (4) ease of learning. BALLI as an instrument for data 
collection is used in several studies (Nikitina \& Furuoka, 2006). Various studies as argued by (Horwitz, 1988; 2013) have explored beliefs from language learners in different sociolinguistic settings.

\section{Semi-structured Interviews}

To triangulate the current research, the semi-structured interviews were conducted, coded and transcribed. The study used the principles of semistructured interview suggested in the research of Patton (2002). This way helped the researcher to illicit detailed and rich information about anxiety and learner beliefs. In the same vein about interviews, Wei (2014) has written that semi structured interviews provide a comprehensive picture of feelings and beliefs which researchers fail to observe and identify directly or through quantitative descriptive analysis. With the use of semi structured face to face interviews, the researcher achieves sound understanding and subjective information which helps him to create balanced view of anxiety and beliefs in research. The participants (male $=05 \&$ female $=05$ ) were voluntarily requested for subjective responses. The purpose was to check whether differences in anxiety and beliefs existed in the study.

\subsection{Data Collection}

Data were collected quantitatively and qualitatively with the purpose to address the issues of anxiety and beliefs in English language learning. Johnson, Onwuegbuzie and Turner (2007) have also favored such research that mixes some components of both approaches in order to provide the broader purposes of breadth and depth of understanding and corroboration. The reasons to conduct methodological pluralism is to verify research purpose or objective, to monitor data collection and probe a data set to discover its meaning.

\section{Data Analysis and Interpretation}

The quantitative data were analyzed through SPSS21. The Independent samples t-test was computed to see the gender differences in anxiety and language beliefs. For the qualitative part, the content analysis method was used to analyse semi-structured interviews. Qualitative content analysis as argued by Hsieh \& Shannon, (2005) that it can be referred to as "a research method for subjective interpretation of the content of text data through the systematic classification process of coding and identifying themes or patterns. 


\subsection{Gender Differences on FLCAS}

Table 4.1

\begin{tabular}{lllllccccc}
\multicolumn{1}{c}{ Group Statistics of FLCAS } \\
\hline Group & $\mathrm{N}$ & Mean & $\mathrm{t}$ & $\mathrm{df}$ & $\begin{array}{c}\text { Sig. (2- } \\
\text { tailed) }\end{array}$ & $\begin{array}{c}\text { Mean } \\
\text { Diff }\end{array}$ & $\begin{array}{c}95 \% \text { C.I } \\
\text { Lower }\end{array}$ \\
\hline CA & Male & 116 & 36.18 & -0.48 & 219 & 0.62 & -0.34 & -1.7 & 1.05 \\
& Female & 105 & 36.53 & & & & & & \\
TA & Male & 116 & 47.47 & -1.20 & 219 & 0.23 & -1.06 & -2.82 & 0.68 \\
& Female & 105 & 48.54 & & & & & & \\
FNE & Male & 116 & 23.11 & 0.06 & 219 & 0.94 & 0.03 & -0.99 & 1.06 \\
& Female & 105 & 23.07 & & & & & & \\
\end{tabular}

CA: Communication Apprehension. TA: Test Anxiety. FNE: Fear of Negative Evaluation

As shown in the table 1, it seems clear from the group descriptive statistics that no difference exist among male and female engineering students. There is a slight difference in test anxiety mean scores $($ male $=47.47 /$ female $=$ 48.54). In general, the accumulative mean scores on communication apprehension, test anxiety and fear of negative evaluation indicates no difference in FLCAS. Moreover, t-test was computed to determine gender difference and it proved that difference existed in the responses of male and female participants about foreign language learning. The subjects experienced somewhat higher levels of anxiety in learning English at MUET Pakistan. Neither male nor female has less levels of apprehension in communication, anxiety in tests and fear of negative evaluation. In other words, both male and female students experienced similar levels of anxiety in learning English.

\subsection{Gender Differences in BALI}

The independent samples t-test was also computed to investigate the gender differences in beliefs about English language learning. 
Table 4.2

Group Statistics on BALLI

\begin{tabular}{|c|c|c|c|c|c|c|c|c|c|}
\hline & \multirow[t]{2}{*}{ Group } & \multirow[t]{2}{*}{$\mathrm{N}$} & \multirow[t]{2}{*}{ Mean } & \multirow[t]{2}{*}{$\mathrm{t}$} & \multirow[t]{2}{*}{$\mathrm{df}$} & \multirow{2}{*}{$\begin{array}{c}\text { Sig. } \\
(2- \\
\text { tailed) }\end{array}$} & \multirow{2}{*}{$\begin{array}{c}\text { Mean } \\
\text { Diff }\end{array}$} & \multicolumn{2}{|c|}{$95 \%$ C.I } \\
\hline & & & & & & & & Lower & Upper \\
\hline Foreign & Male & 116 & 32.31 & 0.94 & 213 & 0.34 & 0.57 & -0.62 & 1.77 \\
\hline $\begin{array}{l}\text { Language } \\
\text { Aptitude }\end{array}$ & Female & 105 & 31.74 & & & & & & \\
\hline Difficulty of & Male & 116 & 21.31 & 0.70 & 219 & 0.47 & 0.27 & -0.48 & 1.02 \\
\hline $\begin{array}{l}\text { Language } \\
\text { Learning }\end{array}$ & Female & 105 & 21.03 & & & & & & \\
\hline Nature of & Male & 116 & 28.10 & -0.8 & 219 & 0.38 & -0.44 & -1.47 & 0.57 \\
\hline $\begin{array}{l}\text { Language } \\
\text { Learning }\end{array}$ & Female & 105 & 28.55 & & & & & & \\
\hline Communication & Male & 116 & 27.18 & -2.6 & 219 & 0.01 & -1.27 & -2.23 & -0.31 \\
\hline Strategies & Female & 105 & 28.45 & & & & & & \\
\hline Motivation and & Male & 116 & 14.94 & -0.8 & 219 & 0.37 & -0.30 & -0.99 & 0.37 \\
\hline Expectation & Female & 105 & 15.25 & & & & & & \\
\hline
\end{tabular}

As shown in the table 2, the group statistics indicate slightly mean score differences in foreign language aptitude, communication strategies and motivation and expectations about English language learning. The mean scores (male $=32.31$; female $=31.74)$ of the participants on foreign language aptitude show that they strongly believe in aptitude for language learning. Moreover, the mean scores of both male and female subjects on communication strategies $(m e a n=27.18)$ and $(m e a n=28.45)$ describe their beliefs about strategies they are using in a classroom for learning English and the expectations and orientations they keep from the target language.

Independent Sample t-test revealed that student's responses on BALLI do not vary. It is revealed that both male and female subjects have similar beliefs about foreign language learning. The results of independent samples t. test indicate no gender differences in this study.

\subsection{Analysis of Interview}

During the semi-structured interviews, this study determines that both male and female subjects have somewhat similar levels of foreign language anxiety. The study has been replicated with the previous research on anxiety (Aida, 1994; Ohata, 2005; Young, 1999; Gopang, 2016; Tanveer, 2007). 


\section{a) Foreign Language Classroom Anxiety}

In terms of anxiety, both male and female respondents agreed that they experienced somewhat higher levels of anxiety in a classroom. Out of 20 interviewees, many of them agree that they are afraid of giving presentations in front of the teacher and classmates. One of the students expressed it saying that ' $I$ cannot give presentation and usually make any excuse during the presentation because I feel nervous in front of all people in a classroom'. Another student told that, 'he always avoided participating in speaking individual activities. The nervousness in speaking and presentation was similarly endorsed by the female students. A female student expressed her nervousness in these words, 'Oh no --no presentation in front of the English teacher, I feel very... very shy and nervous'. I am speaking well with friends but I run out of words during presentation in a class', is uttered by a female participant. 'When the teacher calls me to speak in front of the class. My speaking is ended there I can't say any words. I forget all I do not have control', another female engineering student expressed her anxiety in above words.

In the same vein, many participants including male and female endorsed test anxiety in English class. They reported that they were afraid of tests conducted by the teacher. 'I avoid test because of my mistakes in English', 'speaking is bit ok but testing is terrible experience'. Sometimes, it is fine to test but on regular basis it is not ok with me'. These are some of the expressions of the university undergraduates.

The participants of this study reported that they experienced anxiety in being negatively evaluated in a class. Both male and female students stated that they of course were afraid of negative evaluation by the others. For example, one male students said 'I am afraid of others' comments and smiles in classroom'. 'See sir, you speak but of course you are self-conscious of people around you and I am especially feeling this in English classes. These words of the both subjects suggest their somewhat similar views on communication apprehension, test anxiety and fear of negative evaluation. The qualitative part also confirms the quantitative section that somewhat similar levels of language anxiety in learning classroom.

\section{b) Beliefs about Language Learning}

Regarding to beliefs about language learning, the responses of male and female subjects believed that they somewhat similar aptitude for language learning. They reported that everyone can learn to speak foreign language. All of them have aptitude for language. Children can learn foreign language easily and Pakistanis are good at language learning. In interviews, students expressed their similar views about language learning beliefs. Primarily, similar responses on 
language aptitude, nature of language learning, difficulty of language learning, communication strategies and motivation and expectations. At Mehran UET, the engineering undergraduates reported some common beliefs which they hold about English language learning. Grammar, translation, vocabulary, practice and repetition, listening and speaking in English, learning English with the natives, are mostly common held beliefs among male and female students. 'Grammar is essential as well as vocabulary are very important component parts of the language,' speaking is mandatory for learning English; vocabulary is the only way to learn English I believe. If anything comes to you and you do not understand then there is no use of learning that language;' if you want to learn any language you must learn its grammar. It is important because it teaches us basics of language which make us good learner; I watch English programs. I love English much; primary thing in learning language is our listening. It is self -activity which helps in language acquisition; grammar is father of language and vocabulary is its mother. So these are very important components of English language; to learn foreign language is to learn with natives I believe. These some frequent responses of the subjects on language beliefs support the quantitative findings of the present study.

\section{Discussion}

This research addressed the gender differences in anxiety and beliefs about language learning. The results of t-test showed no gender differences in language anxiety and language beliefs among engineering students. In foreign language anxiety, both male and female experienced the same levels of communication apprehension. In contrast, a slight difference is noticed in test anxiety and fear of negative evaluation. However, this may not be considered statistically significant gender differences in this study. These findings are consistent with previous research in which no gender difference in beliefs was reported (Tercanlioglu, 2005). In contrast, these results vary from research of Nahavandi and Mukundan (2014) who reported that on the basis of gender and proficiency levels, the significant differences was determined in engineering Iranian students' beliefs. Iqbal and Yongbing (2017) researched learner beliefs and variation on the basis of gender differences. Their research found that females held the same beliefs in motivations and expectation as their counterparts. On the contrary, both participants varied in the factor nature of language learning. The difference in other factors such as the difficulty of language learning, language aptitude existed but statistically it was not significant. This research found that male and female students varied in slightly in foreign language aptitude, communication strategies and motivation and 
expectation. On the other hand, the similar results were achieved in difficulty of language learning and nature of language learning.

The foreign language results of this study corroborated with Aida's findings (1994) who also reported no significant difference between male and female students. The results are also consistent with the findings of Waseem and Jabeen' research (2013) which indicated no significant difference in level of language anxiety in gender in Pakistani context. The subjective responses of the participants mostly showed similar beliefs in learning English at the university. Frequently and repeated beliefs were grammar, vocabulary, translation, fluency and accuracy, practice and repetition, environment, thinking and speaking in the foreign language, learning English with the natives. The engineering students held these strong beliefs which might be mentioned as replication of early and current research on BALLI. Commonly held assumptions about foreign language suggest that students' early learning could have been the source of shaping their beliefs. This surprising result supported Horwitz (2016) theory of foreign language anxiety.

\section{Conclusions}

This study helps teachers to be aware of their students' nervousness in English classes. No significant difference in anxiety and language beliefs generate new questions for enquiry in the field of second language research. Students' beliefs about English language learning were discussed. These language beliefs are considered to be misconceptions or erroneous in learning (Horwitz, 2013). During language teaching and learning practices, SLA/EFL instructors should deal students' beliefs carefully A very important part of the current research dealt with an analysis of anxiety and beliefs on the basis of gender at the professional university in Pakistan. Statistically, no significant difference was reported in t-test. Similar to this, no difference was identified in male and female subjects' beliefs about language learning. The engineering students held quite similar set of beliefs and experienced moderate degree of anxiety. Both anxiety and beliefs considerably discussed in literature are known as complex and multi-dimensional topics in SLA research. Significantly, it is concluded that this study attempted to present a holistic picture of Asian students' anxiety and beliefs through a mixed methods research design which concurrently addressed language learning issues in a classroom.

\section{Recommendations}

1. This research has suggested some pedagogical implications though surprising results of anxiety and beliefs about language learning. The engineering 
students' levels of foreign language anxiety indicated that the language instructors may considerably focus anxious learners in a classroom.

2. The teachers should be able to identify students' anxiety levels and address it in a mild manner.

3. This study also suggests a proper treatment to cope with learner's beliefs. At the university, language teachers should not directly correct the incorrect language beliefs of the students rather they should design some activities which directly keep awareness among students who keep strong convictions about language learning.

\section{References}

Aida, Y. (1994). Examination of Horowitz, Horowitz, and Cope's construct of foreign language anxiety: The case of students of Japanese. Modern Language Journal, 78(2), 155-68.

Chao, C. T. (2003). Foreign language anxiety and emotional intelligence: A study of EFL students in Taiwan (Unpublished doctoral dissertation). Texas University, Texas, United States

Cortazzi, M., \& Jin, L. (1996). Cultures of learning: Language classrooms in China. In H.Coleman (Eds.), Society and the classroom (pp.169-206). Cambridge, Cambridge University Press.

Creswell, J. W. (2013). Research design: Qualitative, quantitative, and mixed methods approaches. Sage publications.

Creswell, J. W. (2007). Qualitative inquiry \& research design: Choosing among five approaches (2nd Ed.). Thousand Oaks, CA: Sage.

Dewaele, J. M., \& Thirtle, H. (2009). Why do some young learners drop foreign languages? A focus on learner-internal variables, International Journal of Bilingual Education and Bilingualism, 12(6), 635-649, doi: 10.1080/13670050802549656x

Duxbury J. G. \& Tsai, L. L. (2010). The effects of cooperative learning on foreign language anxiety: A comparative study of Taiwanese and American Universities. International Journal of Instruction 3(1), 3-18. 
Gopang, I. B. (2016). Investigating foreign language learning anxiety among students majoring and non-majoring in English at public sector university, Pakistan (Unpublished Master Thesis). University of Sindh, Pakistan.

Gregersen, T., \& Horwitz, E. K. (2002). Language learning and perfectionism: Anxious and non-anxious language learners' reaction to their own oral performance. The Modern Language Journal, 86(4), 562-570.

Horwitz, E. K. (2016). Preliminary evidence for the validity and reliability of a foreign language anxiety scale, TESOL Quarterly, 50(4).

Horwitz, E. K. (2013). Becoming a language teacher: A practical guide to second language learning and teaching. Boston, MA: Pearson Education/Allyn \& Bacon.

Horwitz, E. K. (2010). Foreign and Second Language Anxiety. English Language Teaching, 43(2), 154-167.

Horwitz, E. K. (1999). Cultural and situational influences on foreign language learners 'beliefs about language learning: A review of BALLI studies. System, 27, 557-576.

Horwitz, E. K. (1987). Surveying student beliefs about language learning. In A. Wenden \& J. Rubin (Eds.), Learner Strategies in Language Learning (pp. 119-129). New Jersey: Prentice Hall, Inc.

Hsieh, H. F., \& Shannon, S. E. (2005). Three approaches to qualitative content analysis. Qualitative Health Research, 15(9), 1277-1288.

Iqbal, S., \& Yongbing, L. (2017). Investigating gender influence on language learning beliefs. European Journal of Education Studies, 3(10) 544-556.

Johnson, R. B., Onwuegbuzie, A. J., \& Turner, L. A. (2007). Toward a definition of mixed methods research. Journal of Mixed Methods Research, 1(2), 112-133.

Mantle-Bromley, C. (1995). Positive attitudes and realistic beliefs: Links to proficiency. The Modern Language Journal, 79(3), 372-386. 
McCarger, D. F. (1993). Teacher and student role expectations: Cross cultural differences and implications. The Modern Language Journal, 77(2), 192207.

Nahavandi, N., \& Mukundan, J. (2014). EFL learners' beliefs about language learning along gender, further education in language institutes \& different proficiency levels. International Journal of Applied Linguistics and English Literature, 3(1), 170-180.

Nikitina, L., \& Furuoka, F. (2006). Re-examining Horwitz's beliefs about language learning inventory (BALLI) in the Malaysian Context. Electronic Journal of Foreign Language Teaching, 3(2), 209-219.

Ohata, K. (2005). Potential sources of anxiety for Japanese learners of English: Preliminary case of interviews with five Japanese college students in the US. TESL-EJ, 9(3), 2-23.

Onwuegbuzie, A. J., Bailey, P., \& Daley, C. E. (1999). Factors associated with foreign language anxiety. Applied Psycholinguistics, 20(2), 217-239.

Patton, M. Q. (2002). Qualitative research \& evaluation methods $\left(3^{\text {rd }}\right.$ ed.). Thousand Oaks, CA.

Sakui, K., \& Gaies, S. J. (1999). Investigating Japanese learners' beliefs about language learning. System, 27(4), 473-92.

Smith, E. R. (2000). Social Cognition. In A. E. Kazdin (Ed.), Encyclopaedia of psychology (Vol. 7, pp. 324-329). Oxford, UK: Oxford University Press.

Tanveer, M. (2007). Investigation of the factors that cause language anxiety for ESL/EFL learners in learning speaking skills and the influence it casts on communication in the target language. (Master's thesis). Faculty of education, University of Glasgow

Tercanlioglu, L. (2005). Pre-service EFL teachers' beliefs about foreign language learning and how they relate to gender. Electronic Journal of Research in Educational Psychology, 53(1), 145-162. Retrieved on December 5, 2017, from www.investigacion-psicopedagogica.org/revista/articulos /5/english/Art_5_58.pdf 
Waseem, F., \& Jibeen, T. (2013). Anxiety amongst learners of English as a second language. An examination of motivational patterns in the Pakistani context. International Journal of Humanities and Social Sciences, 3, 1-16.

Wei, J. (2014). A study via interviews of the Chinese Bouyei college learners' EFL classroom anxiety arousals. Journal of Language Teaching and Research, 5(2), 419-428.

Williams, K. E., \& Andrade, M. R. (2008). Foreign language learning anxiety in Japanese EFL University classes: Causes, coping, and locus of control. Foreign Language Teaching, 5(2), 181-191.

Yang, N. D. (1999). The relationship between learners' beliefs and learning strategy use. System, 27(4), 515-535.

Young, D. J. (1999). Affect in foreign language and second language learning: A practical guide to creating a low-anxiety classroom atmosphere. Boston, MA: McGraw-Hill College.

Zheng, Y. (2008). Anxiety and second/foreign language learning revisited. Canadian Journal for New Scholars in Education, 1(1), 1-12. 